\title{
Sustainability Indicators for Cattle Production System in Kitadin Embalut Post Mining Land, East Kalimantan, Indonesia
}

\author{
Gery Andesitian ${ }^{1}$, Endang Baliarti ${ }^{2}$, Nono Ngadiyono ${ }^{2}$, Bambang Suwignyo ${ }^{3}$, and \\ Tri Satya Mastuti Widi ${ }^{2, *}$ \\ ${ }^{1}$ Graduate Program of Animal Science, Faculty of Animal Science, Universitas Gadjah Mada, Jl. Fauna No 3, Kampus \\ Bulaksumur UGM, Yogyakarta 55281, Indonesia. \\ ${ }^{2}$ Department of Animal Production, Faculty of Animal Science, Universitas Gadjah Mada, Jl. Fauna No 3, Kampus \\ Bulaksumur UGM, Yogyakarta 55281, Indonesia. \\ ${ }^{3}$ Department of Animal Nutrition, Faculty of Animal Science, Universitas Gadjah Mada, Jl. Fauna No 3, Kampus \\ Bulaksumur UGM, Yogyakarta 55281, Indonesia. \\ *Corresponding Author: E-mail: widi.tsm@ugm.ac.id
}

\begin{abstract}
Growing demand for meat in developing countries is expected to double by 2050. In Indonesia, national beef production only satisfy about $45 \%$ of demand. Cattle production is limited by availability of land, particularly in Java Island. Post mining land, mostly located in outside Java, become one of potential areas to raise cattle. In this study we identify stakeholders and determine sustainability issues and indicators for beef cattle production system in Kitadin Embalut post mining land in East Kalimantan. Through literature review, discussion with experts and focus group discussion among stakeholders, the procedures were conducted in three stages, consisting of defining the problem, identifying and analysing relevant stakeholders, then determining Economic, Ecological, and Societal (EES) relevant issues. The EES issues then were translated into sustainability indicators. As a result, by considering the importance role at stake, we revealed farmers, mining company, policy maker and local government as primary stakeholders, while inseminators/veterinarians, butchers and traders were identified as secondary stakeholders. Each stakeholder has different importance to system and interest. Through SW-analysis and considering the criteria of sustainability indicators should be met, a set of economic, environmental and social possible indicators were selected. The conceptual framework and sustainability indicators selection described in this paper are precursors to the assessment of the sustainability indicators contribution to overall sustainability development of cattle system on post mining land.
\end{abstract}

Keywords: Stakeholders, sustainability indicators, beef cattle, production system, post mining land

\section{INTRODUCTION}

Indonesia is an emerging economy with an increasing demand for beef. The government with the program of Accelerating the Achievement of Beef Self-sufficiency is apriority agenda for national livestock development [1] and is aimed at realizing animal food security from livestock. The beef self-sufficiency program is a momentum that has considerable potential and opportunity to be developed so that these potentials and opportunities need to be managed optimally. Beef cattle production is limited by the availability of land, especially in Java, pushing the idea that its development must be optimized outside Java Island [1].
One of the lands using opportunities for the development of beef cattle is post-coal mining land which is widely available in Kutai Kartanegara Regency, East Kalimantan. Mining is a temporary land use, halting when the valuable extractable materials resource is exhausted [2]. The eventual goal of mining rehabilitation is to achieve an acceptable and sustainable post-mining land use [2]. To guarantee that local communities truly benefit from economic development in the long run, a sustainability perspective should be taken [3].

The post-coal mining land in this study area have exhausted its natural resources and is considered nonrenewable is expected to be productive lands with the development of beef cattle farming system. Stakeholder 
participation in establishing post-mining land cover and land use options is critical for long-term success. This paper focuses on 1). Identifying problem regarding to utilisation of coal post mining for beef cattle production, 2). Identifying relevant stakeholders, and 3). Determining Economic, Ecological and Societal (EES) relevant issues and sustainability indicators.

\section{METHODOLOGY}

Kitadin Embalut is a coal mine company in Kutai Kertanegara District, East Kalimantan Province, covers 2.973,6 hectares which consists of sites, namely Embalut, Bangun Rejo, Embalut, Kerta Buana and Separi. Kitadin Embalut has been operating since 1983 and holds a mining concession until 2022. Since 2012, some areas ( 800 ha) of Kitadin Embalut site have been reclaimed and re-vegetated. Under corporate social responsibility (CSR) program, Kitadin Embalut company contributes to community livelihood by farming whose activities including crop and cattle farming. Bali cattle (Bos Javanicus), an indigenous and very adapted breed, is the one that used in this system. To date, the population of Bali cattle in Kitadin Embalut site is around 1,100 heads.Most of the farmers keep their cattle semi intensively, which means cattle are allowed to grazing in pasture on reclaimed post-mining lands during the day and keptin the small barn/shelters during the night. The company built the small barns and fencing around the shelters.

Sustainability assessment is a key step in supporting the development of sustainable farming systems [4]. Indicator-based monitoring tools are frequently applied for sustainability assessments [5], also in farming system and in this study, when integrated on reclaimed post mining land. Relevance (appropriate for the context and objectives), realism (data are available and easy to measure) and end user value (easy for the users to interpret) are often used as selection criteria for indicators [6].

\section{RESULTS}

We identified different stakeholders from prior literature review process, continued by discussions with experts, and focus group discussion with stakeholders, involved in beef cattle production system on reclaimed post - coal mining in Kitadin Embalut. By considering their importance role at stake, we categorised them as primary or secondary stakeholders. The key primary stakeholders are smallholder farmers, mining company, central government as policy maker, and local government (Table 1).

Table 1. Primary and secondary stakeholders in Kitadin Embalut post-coal mining cattle system

\begin{tabular}{|c|l|l|}
\hline Stakeholders & Importance to system & Interest \\
\hline Primary stakeholders & & High capital needed, social status \\
\hline Farmers & Primary producer & Provider of land for community use \\
Mining company & Maintain social image & $\begin{array}{l}\text { Helping to improve human } \\
\text { resources as farmers } \\
\text { CSR program }\end{array}$ \\
\hline $\begin{array}{c}\text { Central Government } \\
\text { (policy maker) }\end{array}$ & $\begin{array}{l}\text { Policy and regulation about post mining } \\
\text { reclamation and determine the land use }\end{array}$ & $\begin{array}{l}\text { Support national programs } \\
\text { Cooperation between government } \\
\text { and company }\end{array}$ \\
\hline Local Government & $\begin{array}{l}\text { Policy of land use and extension delivery } \\
\text { for farmers }\end{array}$ & $\begin{array}{l}\text { Increasing of cattle population and } \\
\text { economic }\end{array}$ \\
\hline $\begin{array}{l}\text { Secondary } \\
\text { stakeholders }\end{array}$ & $\begin{array}{l}\text { Improving livestock health and } \\
\text { reproduction }\end{array}$ & Selection to slaughter \\
\hline $\begin{array}{l}\text { Inseminator/Veterina } \\
\text { Butchers }\end{array}$ & Cattle movements inter areas & Profit \\
\hline \begin{tabular}{l} 
Traders \\
\hline
\end{tabular} & Profit \\
\hline
\end{tabular}


Table 2. Selected sustainability indicators for post-mining cattle system

\begin{tabular}{|l|l|l|}
\hline $\begin{array}{l}\text { Economic, Environmental } \\
\text { and Issues Sustainability } \\
\text { Indicators Social (EES) }\end{array}$ & Issues & Sustainability indicators \\
\hline Economic & Economically benefit & $\begin{array}{l}\text { Farmer's income; Gross margin (GM) Cattle performances } \\
\text { (growth and reproduction rate) }\end{array}$ \\
\hline \multirow{2}{*}{ Environmental } & Land use and quality & $\begin{array}{l}\text { Total land use Soil fertility Feed availability (carrying capacity; } \\
\text { botanical composition) }\end{array}$ \\
\hline \multirow{2}{*}{ Social } & Cattle management & $\begin{array}{l}\text { Farm size, feeding system, mating system, housing recording, } \\
\text { time allocated for cattle keeping }\end{array}$ \\
\cline { 2 - 3 } & Human well-being & Farmer educational level, social status \\
\cline { 2 - 3 } & $\begin{array}{l}\text { Additional functions of } \\
\text { cattle }\end{array}$ & $\begin{array}{l}\text { Social status, saving, insurance, manure, draught power, } \\
\text { culture Health and diseases Cattle diseases or health problems }\end{array}$ \\
\hline
\end{tabular}

Each stakeholder has different importance to system and interests regarding the livestock system in post - coal mining. Farmers have important role in the system to produce the beef cattle and concern to high capital need and increase their social status. On other side, mining company provides lands for cattle farming, as its responsibility to return post-mining areas into productive lands through reclamation and rehabilitation. Cattle farming is one of good options to mitigate the environmental impacts of mining activities and satisfy the societal expectation.

The farmers considered low production cost due to no rent cost for land and the cattle are raised semi intensively, without additional feeds and maintenance costs. One of the advantages of Bali cattle is its adaptability to harsh condition and poor management [7]. Selected defined indicator for economic benefit was represented by gross margin rather than farmer's income, which is based on financial revenues minus variable cost. Calf crop was determined for cattle performance indicator. Growth performance is not selected, due to technical circumstance in the extensive system to measure the cattle. To monitor the impact of cattle system on post mining land and to measure productivity of post mining land, the land use, soil fertility, carrying capacity and botanical composition were selected as environmental indicators. (Table 2).

Societal issues relevant with respect to cattle production system on post mining land are, among others, cattle management which represented by farm size, feeding system, mating system, housing and time allocated for keeping cattle; educational level of the farmers; additional functions of cattle; and health and diseases. The important components to monitor sustainability are, 1.) participatory approaches to identify and select issues and corresponding indicators and 2). the availability of data to empirically assess the indicators for evaluating the introduction of cattle system on post mining land [8]. This study was intended to focus on the first component and was done very carefully to prepare for the second component and next phase, namely assessing the contribution of sustainable indicators to overall sustainability development. A lack of robust procedures for selecting indicators makes it difficult to validate information provided by those indicators [9].

The challenge, then, is to select a set of indicators able to comprehensively and reliably represent the complexity of the system, its current environmental, economic, and social state, and its transition towards sustainability.

\section{CONCLUSIONS}

Introduction of cattle production system on post mining land seems to be beneficial option for responding the satisfying the demand of beef cattle and to mitigate the environmental impact of mining activity. The conceptual framework and sustainability indicators selection described in this paper are precursors to the assessment of the sustainability indicators contribution to overall sustainability development of cattle system on post mining land.

\section{REFERENCES}

[1]. Agus A, Widi TSM. Current situation and future prospects for beef cattle production in Indonesia A review. Vol. 31, Asian-Australasian Journal of Animal Sciences. Asian-Australasian Association of Animal Production Societies; 2018. p. 976-83. 
[2]. Maczkowiack RI, Smith CS, Slaughter GJ, Mulligan DR, Cameron DC. Grazing as a postmining land use: A conceptual model of the risk factors. Agric Syst. 2012 Jun 1;109:76-89.

[3]. De Valck J, Williams G, Kuik S. Does coal mining benefit local communities in the long run? A sustainability perspective on regional Queensland, Australia. Resour Policy. 2021 Jun 1;71:102009.

[4]. Lebacq T, Baret P V, Stilmant D. Sustainability indicators for livestock farming. A review. Agron Sustain Dev [Internet]. 2013;33(2):311-27. Available from: https://doi.org/10.1007/s13593012-0121-x

[5]. Meul M, Van Passel S, Nevens F, Dessein J, Rogge E, Mulier A, et al. MOTIFS: a monitoring tool for integrated farm sustainability. Agron Sustain Dev [Internet]. 2008;28(2):321-32. Available from: https://doi.org/10.1051/agro:2008001

[6]. Hiemstra S, Eaton D, Xuan Trach N, Hao P. Indicators to monitor livestock genetic diversity
Cạnh tranh ngành Chăn nuôi và An toàn thực phẩm (LIFSAP) View project MEKARN: Research cooperation on livestock-based sustainable farming systems in the lower Mekong basin View project [Internet]. 2006. Available from:

https://www.researchgate.net/publication/401123 86

[7]. Martojo H. Indigenous Bali cattle: the best suited cattle breed for sustainable small farms in Indonesia. Relatsh between Indig Anim Humans APEC Reg. 2003;21-35.

[8]. Widi TSM, Udo H, Oldenbroek K, Budisatria IGS, Baliarti E, der Zijpp A van. Designing genetic impact assessment for crossbreeding with exotic beef breeds in mixed farming systems. Outlook Agric [Internet]. 2020 Apr 9;50(1):3445. Available from: https://doi.org/10.1177/0030727020915206

[9]. Dale VH, Beyeler SC. Challenges in the development and use of ecological indicators. Ecol Indic. 2001 Aug 1;1(1):3-10. 